Proceedings of the Institution of
Civil Engineers
Municipal Engineer I57
September 2004 Issue ME3
Pages $209-220$
Paper 13568
Received 19 November 2003
Accepted 29 June 2004
Keywords:
recreational facilities/social impact/
urban regeneration

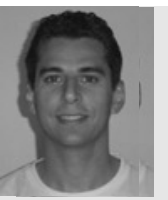

Maximos Malfas Enterprise Consultant, lonian Island Centre for Business and Technologica Development, Greece

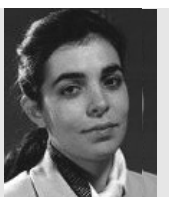

Eleni Theodoraki Lecturer, Institute of Sport and Leisure Policy, School of Sport and Exercise Sciences, Loughborough University, UK

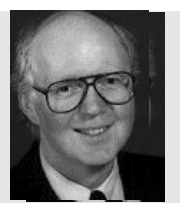

Barrie Houlihan Professor, Institute of Sport and Leisure Policy, School of Sport and Exercise Sciences, Loughborough University, UK

\title{
Impacts of the Olympic Games as mega-events
}

\section{Malfas PhD, E. Theodoraki PhD and B. Houlihan PhD}

Mega sporting events can be defined by their impacts and complexity in organisation and delivery. This paper reviews the literature on the features of such events and, drawing particular examples from recent Olympic Games, it identifies the nature and extent of their impacts on the host country and community. These range from the political, social, economical, physical and cultural and can be negative as well as positive. The paper concludes that while the prospect of economic growth is the driving force behind bids for hosting the Olympic Games, the legacies that follow their hosting are difficult to quantify, prone to political interpretation and multifaceted.

\section{INTRODUCTION}

In recent years, the Olympic Games have developed into one of the most significant mega-international sporting events. ${ }^{1}$ The increasing number of cities bidding to host the Olympics and the increasing funds invested in Olympic bids indicate that local leaders perceive the securing of such an event as an opportunity to improve economic and social aspects of a city or region through the accumulated investment triggered by staging the Games. As a result, in the course of the past two decades there has been increased interest on the impact of the Olympics on the socio-economic and political life of the host city, region and country. The Olympic Games are therefore examined in relation to other mega-sporting events, such as the football World Cup and world championships but also in relation to commercial and cultural events, such as Expos and festivals, since it has been claimed that regardless of their character, events such as the aforementioned generate similar dynamics for the host cities or regions. Here, however, it is suggested that an analysis of the character of the contemporary Olympic Games should not treat them as merely a typical mega-event, since they possess a number of distinctive characteristics. These special characteristics are primarily derived from the fact that the Games are presented and promoted as the prime expression of the philosophy of Olympism, and are also organised within a strict institutional framework set by the International Olympic Committee (IOC).

Professionals in the host environment such as town planners, engineers and architects naturally become vital players of the Olympic Games preparation, since the staging of the event usually requires large-scale construction projects in both sporting facilities and supporting infrastructure such as housing facilities, road constructions, redeveloping of the host city buildings and landmarks and the like. In view of the above, this paper aims to exemplify the range of impacts of the contemporary Olympic Games in the host cities and countries from a mega-event perspective. In doing so, the reader acquires a holistic picture of the key agents involved in the preparation of the event and their various interests and roles within the Olympic organisation network. The paper is structured in two parts. The first explores the institutional particularities of the Olympic Games and exposes their unique organisational characteristics and implications for planners and organisers. The second explores the significance of the contemporary Olympic Games within the spectrum of mega-sporting events by critically evaluating their impacts on the host cities, regions and countries. In discussion, the range and diversity of interests as well as the high stakes involved in the hosting of such events are uncovered.

\section{OLYMPISM, THE OLYMPIC MOVEMENT AND THE MODERN OLYMPIC GAMES}

The institution of the modern Olympic Games was established in 1896 by Baron Pierre de Coubertin, a visionary educator who claimed that international sport could foster individual and collective goodwill and even contribute to world peace. ${ }^{2}$ The modern Games, therefore, were revived as an expression of an ideology and philosophy, that Coubertin called Olympism. It has been claimed that Olympism grew from Coubertin's initial goal of revitalising the youth of France through a global ideology that could embrace sport for all males. ${ }^{3}$

The Olympic Charter describes Olympism as a "philosophy of life, exalting and combining in a balanced whole the qualities of body, will and mind', which, by blending sport with culture and education, seeks to create a way of life based on the joy found in effort, the educational value of good example and respect for universal fundamental ethical principles (see Fundamental Principles \$2 of Ref. 4). Consequently, the goal of Olympism is to 'place everywhere sport at the service of the harmonious development of man, with a view to encouraging the establishment of a peaceful society concerned with the preservation of human dignity' (see Fundamental Principles $\$ 3$ of Ref. 4). 
The Olympic movement includes the International Olympic Committee, the International Federations, the National Olympic Committees, and all the associations, clubs and individuals belonging to them (see Reference 4, Rule 3 1). The International Olympic Committee is the central power of the Olympic movement consisting of 125 members drawn from a relatively wide variety of countries. Members are appointed by the IOC itself, and more specifically by its President and Executive Board. ${ }^{5}$ This committee also holds the power to select the city to stage the Olympics.

There is no doubt that contemporary societies place a high premium on the ideals of Olympism. However, the institution of the Olympic Games, which is the most prominent expression of Olympism, has also attracted considerable criticism, especially during the past couple of decades. The focus of the criticism has been the Olympic Movement-that is, the international sport alliance which has derived from Olympism, and particularly the International Olympic Committee, which has ultimate control over it. Examples of such criticism include revelations about corruption in the upper echelons of the movement, doping and the extensive commercialisation and commodification of the athletes and the events. ${ }^{6}$

The National Olympic Committee of the host country forms an Organising Committee of the Olympic Games, which, in turn, cooperates with various entities, such as the International Olympic Committee, the International Federations, governments and the private sector in order to ensure the best possible facilities and environment for the athletes and visitors as well as the smooth transaction of the Games. The organisation of the Olympic Games is a complex system which has as its central constituent the Organising Committee (see Reference 4, Rule 31 and Bye-Law to Rule 20, \$2.5).

In recent years the Olympic Games have become an economically significant event, primarily as a result of the increasing commercialisation of sports. Since Los Angeles, the financial investment in Olympic Games has increased dramatically. ${ }^{7}$ For example, the television rights alone for the 1996 Atlanta Games cost US $\$ 872$ million, for the Sydney 2000 Games US $\$ 1 \cdot 12$ billion, ${ }^{8}$ while for the Athens 2004 Olympic Games the television rights holders are due to pay an estimated total of US $\$ 1.7$ billion. ${ }^{9,10}$ In view of this commercial success and in anticipation of its continuation, the International Olympic Committee encouraged a substantial increase of the size of the Olympic games. Since 1984 every Olympic Games has been bigger than the previous one, in terms of numbers of competitions and of participating athletes (Table 1).

The International Olympic Committee's major exertion of power, however, is based on its economic control over the Games. It has been claimed that this control was tightened considerably after the organising committee for the 1984 Los Angeles games successfully demonstrated how the Games could be organised to maximise income from television rights, sponsorship and merchandising, and make a financial surplus over costs. ${ }^{12}$ The IOC now determines in detail the nature of the event with regard to its financing and contributes as much as $60 \%$ to an organising committee's budget. ${ }^{8}$ It has exclusive control of the negotiations of the television rights and the international sponsorship programmes for the Games, and keeps part of the

\begin{tabular}{|ccccc|}
\hline Games & Nations & Athletes & Sports & Events \\
\hline 1984 & 140 & 6797 & 23 & 221 \\
1988 & 159 & 8465 & 25 & 237 \\
1992 & 169 & 9367 & 28 & 257 \\
1996 & 197 & 10320 & 26 & 271 \\
2000 & 199 & 10651 & 28 & 300 \\
Table 1. The growth of the Summer Olympic Games & \\
\hline
\end{tabular}

relevant funds for internal administration and for its constituents. The money coming into the Olympic Movement often reaches exceptional amounts, especially if we consider that the television rights contracts alone for each Games typically exceed $\$ 1$ billion. ${ }^{8}$

\section{DEFINING MEGA-EVENTS}

The initial step in defining sporting mega-events is to consider them within the field of other non-sporting events since most of the relevant research and analysis incorporates events of various types (e.g. commercial, cultural). Therefore, the key issue to be addressed is the identification of the criteria by which mega-events in general ought to be defined. In other words, the central question is: 'How are mega-events distinct from other events?' A mega-event can be viewed in two main respects: first, with regard to its internal characteristics-that is, primarily its duration and its scale (i.e. number of participants and spectators, number of individual sessions, and levels of organisational complexity); and second, in respect of its external characteristics, which mainly take account of its media and tourism attractiveness, and its impact on the host city.

The internal characteristics of an event alone have attracted limited attention since researchers are primarily concerned with the external implications of an event, and also in some cases it has been found that some internal and external elements of an event are not necessarily interrelated. Ingerson, ${ }^{13}$ for example, has found that in Australia in 1998, events with limited duration and media attractiveness made a bigger economic contribution than other longer-lasting events with bigger television audiences. Therefore, mega-events are usually perceived as having an impact on local tourism and economy. ${ }^{1,14,15}$

Expenditures on facility and infrastructure preparation, as well as revenue from visitor spending, tickets and media exposure, form the baseline of the bulk of mega-event analysis. However, in looking even further, it has also become evident that megaevents can be analysed as tools of government policy or expressions of political ideologies. ${ }^{16}$ Furthermore, mega-events can be assessed in terms of their role in the process of capital accumulation through corporate sponsorships and media audiences. ${ }^{17}$ Mega-events have also received attention in relation to the urban processes involved, such as the erection of landmark structures and the renewal of urban space, with particular examples being the extensive waterfront development in Barcelona for the 1992 Olympics, ${ }^{18}$ and the refurbishment of the Homebush area in Sydney for the 2000 Olympics. ${ }^{19}$

Sensibly, therefore, authors' attempts to determine the criteria for defining a mega-event reflect the areas of their interests, which, as mentioned above, mainly focus on their external 
characteristics and impact. Extensive attention has been paid to the argument that the extent of media coverage and particularly television coverage, and the associated attraction of sponsorship determine whether an event may be described as a mega-event or not. ${ }^{20}$ More specifically, Roche ${ }^{1}$ has claimed that the degree of media interest in an event (i.e. local, national, global) will effectively define the type of event. In effect, Roche ${ }^{1}$ has suggested that the significance of an event depends upon the kind of media coverage it can attract and the degree to which it can become a national or international 'media event'.

Although the levels of media attractiveness have been the centre of much mega-event analysis, ${ }^{21-23}$ particular cases suggest that this criterion alone cannot determine the status of a mega-event. The 1991 World Student Games in Sheffield, for example, had poor media coverage and poor associated sponsorship, thus creating a major debt for the organisers. ${ }^{24}$ However, this event had a significant economic impact on the city of Sheffield and was also the starting-point of an ongoing regeneration of the city, which has gradually created a highprofile sporting image within the UK. ${ }^{25}$ Similarly, in Australia in 1998, the Spring Racing Carnival made a bigger economic contribution (\$174 million) than other more prestigious events such as the Formula One Grand Prix (\$96 million) or the Australian Tennis Open (\$70 million), while having the lowest estimated television audience (300 million, 500 million and 600 million respectively). ${ }^{13}$

Although the media-related aspect of events is rarely overlooked when authors attempt to classify an event, the focus is undoubtedly placed upon the consequences of an event on the host city, region or even country. Roche, ${ }^{24,26}$ for example, has suggested that the criteria for determining a mega-event should be sought in the impacts, primarily economic ones, the event has on the cities that stage them. In more detail, Sola ${ }^{27}$ suggests that mega-events usually have an extraordinary impact on the host area in terms of one or more of the following: "tourist volumes; visitor expenditures; publicity leading to a heightened awareness and a more positive image; related infrastructural and organisational developments which substantially increase the destination's capacity and attractiveness'. It is claimed, therefore, that the degree and significance of the impact of an event on the host city or region mainly determine whether the event should be termed a 'mega' one. In effect, the notion is adopted here, that mega-events are those sporting, commercial or cultural occurrences whose impacts are significant for the cities, regions or countries that stage them.

Moreover, it is accepted within the relevant literature that cities' motives behind the decision to stage a mega-event are its potential positive consequences, and predominantly its contribution to economic development and urban regeneration. ${ }^{1,28-33}$ Dunn and McGuirk ${ }^{34}$ claim that the hosting of mega-events has become a global imperative of competition between nations, regions and even individual cities, which try to attract international investment. More specifically, they claim that 'place-competition' and 'place-marketing' are the effects of global competition and capital mobility in the contemporary borderless world. In that sense, the internationalisation of capital can enhance the mega-event as a form of 'place marketing' for inward investment. ${ }^{35}$
Indeed, cities and regions are nowadays becoming increasingly concerned with promoting local economic development within their own boundaries, which involves different forms of restructuring of the city, region or even country, such as physical restructuring that enhances the repackaging of the location's identity. According to Graham and Marvin ${ }^{36}$ the contribution of what he calls 'hallmark events', such as the Olympics, to strategies for urban regeneration is strongly associated with 'post-Fordism' and with the related transitions from industrial to post-industrial society and from modernity to post-modernity. Similarly, Harvey ${ }^{37}$ refers to mega-events as one of the main products of post-modern society and a key means by which cities express their personality, enhance their status and advertise their position on the global stage. The bottom line, therefore, is that both globalisation and the economic restructuring of cities have been powerful factors in enhancing the attractiveness of megaevents as stimulants to urban economic development. ${ }^{1,38,39}$ It has been claimed, for example, that the economic decline of old manufacturing cities such as Manchester in a post-Fordist environment led to the conceptualisation of its 1996 Olympic bid as a tool of urban regeneration in what was billed as the 'Regeneration Games'. ${ }^{40}$

Mega-sporting events include specialist world-level international sports competitions (e.g. the World Cup competitions in soccer, athletics, rugby and Grand Prix events for horseracing and motor racing) and also the 'world regional-level' versions of these events. These are mainly connected to the multi-sport Olympics, such as the Asian Games, the Pan-American Games and the Commonwealth Games, and to a lesser degree to the world-level specialist events such as the European zone competition for the soccer World Cup. ${ }^{1}$ Such mega-sporting events provide great opportunities for regions and cities to develop internationally competitive investment environments. Through the processes of place-competition and the restructuring they promote, regions and cities can benefit in the long term. In order to stage the Olympics, for example, considerable investment is required in both sporting facilities and supporting infrastructure, e.g. accommodation for the Olympic family members as well as tourists, transportation, telecommunications etc. (Table 2).

In the same context, mega-sporting events the size of the Olympics or the football World Cup can promote economic activity as a result of the jobs created by the vast numbers of tourists visiting the city before, during and after the event. ${ }^{42}$ The construction of sports facilities can also play a role in programmes of urban renewal by, for example, introducing

\begin{tabular}{|c|c|}
\hline $\begin{array}{l}\text { Sydney } 2000 \text { Summer } \\
\text { Olympics }\end{array}$ & $\begin{array}{c}\text { Salt Lake City } 2002 \text { Winter } \\
\text { Olympics }\end{array}$ \\
\hline $\begin{array}{l}200 \text { National Olympic } \\
\text { Committees } \\
\text { I0 } 65 \text { I athletes ( } 4069 \text { women, } \\
6582 \text { men) } \\
300 \text { events } \\
46967 \text { volunteers } \\
\text { I6 } 033 \text { media ( } 5298 \text { written } \\
\text { press, } 10735 \text { broadcasters) }\end{array}$ & $\begin{array}{l}77 \text { National Olympic } \\
\text { Committees } \\
2399 \text { athletes ( } 886 \text { women, } \\
1513 \text { men) } \\
78 \text { events } \\
22000 \text { volunteers } \\
8730 \text { media ( } 266 \text { I written } \\
\text { press, } 6069 \text { broadcasters) }\end{array}$ \\
\hline
\end{tabular}


new sporting and recreational facilities into previously underprovided areas. On a broader scale, preparations for the event can also provide a means of justifying new investment in transport infrastructure and in projects to enhance the city's landscape and physical appearance. Even unsuccessful bids for the Olympic Games can bring benefits, one example being, through the urban projects and regeneration initiated in order to strengthen the city's Olympic bid. ${ }^{43-45}$

In effect, cities' motives for wishing to stage mega-sporting events are largely derived from the stimulus to promote local economic development and urban regeneration. ${ }^{31}$ The realisation that mega-sporting events can be utilised in such a manner was firstly comprehended with the 1984 Los Angeles Olympic Games. ${ }^{7}$ These Olympics had a limited contribution to the local urban development; however, their substantial commercial success, which resulted from increased television income and corporate sponsorship, and the subsequent surplus of US $\$ 215$ million produced by the organisers, showed that the staging of sporting events the size of the Olympics can become a profitable business for host cities and regions. ${ }^{29}$ The most significant mega-sporting event in terms of economic and urban development has since been the 1992 Barcelona Olympics. These Olympics had a substantial impact on the local economy, and their preparations triggered public investment of US $\$ 6.2$ billion (1995 prices) for redeveloping the city of Barcelona as well as the province of Catalonia. ${ }^{8}$

Therefore, the hosting of mega-sporting events with the diverse benefits that it can promote, naturally involves various interests ranging from governmental initiatives for urban development to profit-oriented initiatives of the private sector. As a result, organisers frequently have to deal with diverse and often conflicting interests, which means that they have to perform a highly complex task. In order to improve the definition of a mega-sporting event, one needs to add to the degree of its impacts, its internal determinants which include the scale or duration as well as its organisational complexity and the involvement of diverse entities such as governments, private corporations and public groups.

\section{THE IMPACTS OF MEGA EVENTS}

The impacts of mega-sporting events on the host city or region can be immense and manifold, and a great part of the relevant literature supports the idea that such events can primarily produce positive outcomes. Whether mega-sporting events do indeed produce such net effects, however, has been under debate by several authors. In the following sections, the impacts of mega-sporting events are discussed in succession with considerable focus on the relevant contradictory arguments.

\section{I. Socio-economic impacts}

It is often argued that the most important reason behind the decision of a city, region or country to host a mega-sporting event is the potential positive impact of the event on the local economy, which in turn can improve the social status of the host community. According to Crompton, ${ }^{46}$ the economic impact of an event can be defined as the 'net economic change in the host community that results from spending attributed to the event'. In that sense it is necessary to comprehend that the direct income of a mega-sporting event-that is, from sources such as ticket sales, television rights and sponsorship deals-does not necessarily contribute to the economic development of the host community, since such income usually covers the costs for organising the event itself. ${ }^{47}$ The economic contribution of mega-sporting events is primarily thought of in terms of the possibilities they provide of increasing the awareness of the city or region as a tourism destination and the knowledge concerning the potential for investment and commercial activity in the region. Therefore, they can attract more investment and visitors, and consequently create new jobs and contribute to the economic growth of the city or region. ${ }^{29,48-50}$

On this basis, the bulk of the literature concerned with evaluating the socio-economic benefits associated with a particular sporting event draws attention to the effects of the event-related job creation on the unemployment rates of the host region, ${ }^{51}$ the effects of the visiting spectators and the media-related advertisement on the tourism industry of the host city or region ${ }^{38,53-55}$ as well as the effects of the event on the social standards of the host community. ${ }^{12,56}$ The latter primarily stresses the event-related impacts on the economic status of the citizens, and the role of the event with regard to the issues of poverty and social exclusion.

With regard to the issue of job creation, undoubtedly a megasporting event can generate large number of jobs, not only those directly associated with the organisation of the event itself but also those in the tourism and retail industry due to the increased volumes of spectators/tourists, and in the construction industry especially when the staging of the event requires major infrastructural development, such as in the case of the Olympic Games. For example, in Atlanta, the host city of the 1996 Olympic Games, an investment of $\$ 2$ billion was made in Olympic-related projects between the 1990 Olympic announcement and spring 1996. As a result, over 580000 new jobs were created in the region between 1991 and 1997. Research commissioned by the Atlanta Convention and Visitors Bureau estimated that the cumulative economic impact of the Olympic Games between 1991 and 1997 was $\$ 5 \cdot 1$ billion. ${ }^{57}$ Barcelona, the host city of the 1992 Olympic Games, had a similar experience, when, from October 1986 to July 1992, the general rate of unemployment fell from $18 \cdot 4 \%$ to $9 \cdot 6 \% .^{58}$

Although it should be accepted that the staging of a megasporting event evidently generates new jobs, attention should be placed on the quality and duration of these jobs. As Schimmel ${ }^{59}$ points out, sporting events create service-related jobs which are often part-time or low-paying. In his analysis of the Cape Town 2004 Olympic bid, Hiller ${ }^{60}$ reaches a similar conclusion and suggests that the vast majority of the anticipated jobs would have been low-payed and short-lived. Moreover, Miguelez and Carrasquer $^{51}$ reported that the Barcelona Olympics generated only a limited number of new permanent jobs since most of the Olympic-related jobs were temporary.

Related to the issue of job creation and to the broad economic development of the host city, region or even country is the boost to the tourism industry due to the staging of a mega-sporting event. For example, it has been reported that the tourism boom during the 1996 Football European Championships helped push 
Britain's trade balance into its first surplus since the beginning of 1995. In total, over 280000 visiting spectators and media came to the UK to attend Euro'96 matches, spending approximately £120 million in the eight host cities and surrounding regions during the three weeks of the championship. ${ }^{61}$ Similarly, during the 1998 Football World Cup in France, between 10 million and 15 million people visited the country because of the event, spending an estimated half a billion pounds on hotels, travel and food. ${ }^{62}$

Morphet ${ }^{20}$ has argued that the role of the media is vital in terms of creating awareness of the host city or region. He has claimed that once the media has been in these event cities, they are never the same because 'like former celebrities, these cities expect a certain respect and recognition long after their moments of glory have been faded from the memory'. Research showed, for example, that the televised production of England's cricket tour to the West Indies increased package tourism to those islands by as much as $60 \% .{ }^{63}$ Moreover, Ritchie and Smith's ${ }^{64}$ five-year study of the image of Calgary before and after the 1988 Winter Olympic Games, revealed that the Games had a dramatic impact on the levels of awareness and knowledge of the city of Calgary in Europe and the United States when compared to other Canadian cities. Similarly, in 1996, during the 17 days of the Centennial Olympic Games, it has been reported that two million people visited Atlanta and 3.5 billion people saw the city on worldwide television coverage in 214 countries and territories, and as a result, the tourist industry of the region increased dramatically. ${ }^{57}$

Research, however, indicates that extensive media coverage of a mega-sporting event can not guarantee a different tourist image for the host city or region. For example, a study conducted in Gothenburg, Sweden, two months before and after the staging of the 1995 Athletics World Championships, looking at the effects of the event on foreign tourists' perceptions of the destination image, revealed that very few of the foreign tourists travelling to Gothenburg connected the games with the city, although the event was the biggest ever sporting event to have taken place in the city and the largest in the world that year. ${ }^{65}$ It was claimed that although the media coverage was intensive, it was focused on the sporting activities, and as a result, very little information was transmitted about Gothenburg. ${ }^{65}$ Moreover, contrary to the vast majority of tourism impact studies of mega-sporting events, that undertaken by Pyo et al. ${ }^{52}$ reviewed the tourism impact of the Olympic Games from 1964 until 1984 and found that their overall impact was negative. These results were later supported by Kang and Perdue ${ }^{53}$ who have criticised tourism impact studies of events, such as the Olympics, for overestimated policy approaches and 'short-terminism'. By employing a long-term view on the Seoul Olympics they found that the event did not have a long-term impact on local tourism. As regards Greece, recent reports on tourist arrivals in 2003 and early 2004 show a small drop in visitor numbers to the islands while figures for Athens show a clear drop. The Athens tourist authorities argue that visitors stay away amid fears of public works and renovations taking place in visitor attractions as these are being prepared for the major influx later in the year. ${ }^{66}$

The discussion above supports the argument that mega-sporting events have a positive economic impact on the host cities, regions or countries, but also suggests that the economic contribution of such events might lie in a single impulse of increased demand during the period of the event, and consequently it might lose its effect in a short period of time. It is sensible, therefore, for one to consider whether the argument, which claims that mega-sporting events can be of enormous benefit to the host community, is valid. It has been claimed, for example, that the economic growth generated from such events may actually make the life of low-income residents more difficult. Hall and Hodges, ${ }^{67}$ for example, emphasise the effects of a mega-sporting event on the house market and land values. They have claimed that the building of event-related infrastructure can involve housing relocation because of the compulsory purchase of land for clearance and building, and it can also lead to a rise in rents and house prices. Consequently, this can cause problems for people living on low incomes in these areas.

The 1996 Atlanta Games serves as an illuminating case of the negative social impacts of a mega-sporting event. A task force that investigated the social impact of the Games reported that 15000 residents were evicted from public housing projects which were demolished to make way for Olympic accommodation. Moreover, between 1990 and 1995, 9500 units of affordable housing were lost, and $\$ 350$ million in public funds was diverted from low-income housing, social services, and other support services for homeless and poor people to Olympic preparation during the same period ${ }^{68}$ In addition, homeless shelters were converted into backpacker accommodation during the Games, since human services organisations were offered financial incentives to convert their services for two weeks to accommodate tourists rather than low-income people. ${ }^{12}$ Similarly, in Sydney, in 1998, when the Olympic-related infrastructure was at its peak, house prices rose $7 \%$ above inflation, compared to the usual 2\%. ${ }^{69}$ Moreover, in Sydney's Olympic corridor, an area which was primarily occupied by low-income tenants and where unemployment was as high as $38 \%$, rents increased up to $23 \%$ in the period $1997-1998 .^{70}$

Consequently, mega-sporting events, such as the 0lympics, could serve to exacerbate social problems and deepen existing divides among residents. ${ }^{71}$ In Atlanta, for example, there were numerous reports of broken promises by the Olympic organisers regarding the poverty issue, in a region where 30\% of the population lived below the poverty line. ${ }^{68}$ 'Street sweeps' were made shortly after Atlanta won the bid when attempts were made to criminalise poverty at the state level via several bills, such as that which made it unlawful to remove any item from a public trash container! ${ }^{12}$ The Task Force for the Homeless reported that the cost to the taxpayer for using the city jail as a shelter for the homeless people arrested under these measures was $\$ 57$ per day. ${ }^{68}$

The latter example raises the concern that when state and federal governments contribute to the staging of a mega-sporting event, they inevitably make use of public money. Although one could claim that tax money can be used for projects upon which an elected government decides, when an event creates public debts, citizens are unfairly taxed to pay off these debts. ${ }^{12}$ Nagano, for example, the host city of the 1998 Winter Olympic Games, faced severe financial consequences for hosting such a big event and taxpayers suffered debts of up to $£ 20000$ per household to balance the city's books. ${ }^{29}$ Other examples include the city debts created from hosting the 1976 Olympics in Montreal and the 1991 World Student Games in Sheffield. ${ }^{31}$ 
To conclude, when the socio-economic impact of a megasporting event is assessed one should take into account a number of vital considerations. First, it is of decisive importance whether the host city manages to use the one-time economic impulse of such an event to change its structure in a way that will provide a self-sustaining process through, for example, permanent tourism, industrial settlements, regular follow-up events or even new economic relations with other regions or countries. ${ }^{72}$ Second, it needs to be comprehended that the extent of the benefit for the overall economy depends on the economic situation of the city when event-related investments are realised. A phase of increased investment activity and increased consumption expenditure in line with an economic upswing or boom may weaken the positive economic benefits. Conversely, if event expenditures are made during an economic recession these will be considerably strengthened. The Olympic Games of Munich 1972, Barcelona 1992 and Atlanta 1996, for example, were fortunate in that their investments fell in an economically weak phase, while those of Seoul 1988 probably led to crowding-out effects. ${ }^{8}$ This is supported by Hughes ${ }^{38}$ study undertaken to provide background information for Manchester's ultimately unsuccessful bid for the 1996 Olympics, which concluded that such an event can have positive impacts on the cities which have an undeveloped sport infrastructure and which have high unemployment, and less so in cities with a developed infrastructure and low unemployment. Finally, as Preuss ${ }^{47}$ points out, cost-benefit analyses or economic impact studies are frequently ordered by the organising authorities of an event, and consequently, the results which the client favours can be produced, since there are some uncertain quantities and qualities, mostly of a social nature, which are easy to manipulate. ${ }^{47}$ Therefore, one should bear in mind that a cost-benefit analysis of a mega-sporting event could be influenced in a way to bring out the desired results.

\subsection{Socio-cultural impacts}

If one looks at a mega-sporting event solely as a sporting festivity, it can be argued that such an event will provide sociocultural benefits for the host region. For example, sporting events the size of the Olympics can increase the local interest and participation in sporting activities, ${ }^{73}$ and also, as Essex and Chalkley ${ }^{29}$ have claimed, they can strengthen regional traditions and values, and increase local pride and community spirit. As Nelson Mandela clasped the world cup in triumph after Africa was awarded football's showcase competition for the first time, millions of people celebrated for what was hailed as deeply symbolic and a major step in the regeneration of a continent. Closer to home Barbara Cassani from the London 2012 bid committee claims that the greatest sporting and cultural on earth will raise national pride and give the chance to show the country at its best. ${ }^{74}$

Increased sports participation can make a significant contribution to the quality of life of both the individual and community. Hooper ${ }^{75}$ has argued that increased sport participation provides a sense of well-being through fun and enjoyment, leading to self-fulfilment and achievement, and encourages social interaction and cohesion for those who may feel socially excluded. For example, Barcelona saw a notable increase in the participation of new social sectors of the population in active sports in the years following the hosting of the Olympic Games. There has been an increase of 46000 new users in the city's sports centres following the 1992 Games, with the percentage of women participating in sporting activities increasing from 35\% in 1989 to 45\% in 1995. Moreover, in 1994, more than 300000 people took part in sporting events which involved the city's inhabitants on the streets of Barcelona, such as athletic competitions, popular marathon, the bicycle festival and the roller-skating festival. ${ }^{76}$ It has been claimed that Catalans' drift into mass-community sporting activities was due to an increased community spirit triggered by the 1992 Olympics. Truno, ${ }^{76}$ for example, found evidence of increased civic pride during the Olympics and remarked that 'the citizens have turned the city's streets into the world's largest stadium'. This was also boosted by media coverage, which was presenting Catalans as among the most celebrative people in Europe. ${ }^{77}$ Similarly, a survey of the residents of the State of Georgia (USA), undertaken by the Governor's Department, confirmed that the 1996 Olympics generated civic pride, with 93\% stating that the Games were positive for the community spirit of the city. ${ }^{57}$ A similar phenomenon was evident during the 1996 European Football Championship in England, where the country adopted the nostalgic theme 'football's coming home', and created a sense of national purpose, national unity and national pride. ${ }^{20}$ The hosting of mega-sporting events, therefore, can provide localities with an opportunity to generate world recognition and reinforce their local pride and community spirit.

Mega-sporting events can also contribute to transforming the image of the host city. The city of Sheffield, for example, which was traditionally a manufacturing city, after the industrial recession of the 1980s and subsequent job losses, adopted sport, leisure and tourism as part of the reimaging strategy of the city. Under that approach, the hosting of mega-sporting events was seen as an integral part of that strategy. ${ }^{24}$ The successful bid for the 1991 World Student Games and the subsequent investment of $£ 139$ million in sporting infrastructure in addition to a further $£ 600$ million in associated leisure and cultural facilities by the early 1990s has given the city a new focus. In 1995 Sheffield was designated by the Sports Council as the UK's first 'National City of Sport' in recognition of its ongoing contribution and commitment to sport, and in December 1997 it was named as the city chosen to host the headquarters of the UK Institute of Sport, ${ }^{25}$ a decision which was however subsequently reversed due to governing body unwillingness to relocate there. ${ }^{78}$ Since the events of September 11th in New York, security issues have taken on a higher profile during the Olympic Games as the need for effective crowd control, security and policing are important aspects. However, organisers need to be cautious to ensure that negative psychological impacts do not arise due to too much security. ${ }^{49}$ The history of removal of prostitutes and beggars, the homeless and protesters as well as the increased powers of police to detain suspects show the efforts of the organisers to show a good image, conveniently forgetting the civil liberties issues at stake.

\subsection{Physical impacts}

Mega-sporting events can also create opportunities for the construction of new sporting facilities as well as the improvement of the physical environment of the host city. The staging of multi-sporting events such as the Olympics or the Commonwealth Games often involves the building of new sporting facilities or the restructuring of existing ones in order 
for the organisers to be able to satisfy the requirements of staging multiple sports in a short period of time. Moreover, the great numbers of participants and officials as well as tourists associated with the event usually require the construction of new roads and the development of the public transport network to ensure their efficient transportation to the sporting venues during the event. In addition, infrastructural development that is not directly related to the event often takes place, such as leisure facilities, commercial centres and open spaces, which aim to improve the physical appearance of the host city or region. Consequently, it has become increasingly common for mega-sporting events to be used as a trigger for large-scale urban improvement. ${ }^{31}$

Perhaps the best example of a mega-sporting event being used in this way was the 1992 Barcelona Olympics, where major investments were made for new transport systems and for the rejuvenation of a run-down coastal area which now has a new marina, leisure facilities and attractive sandy beaches. ${ }^{29}$ It has been argued that the Olympic Village (Parc de Mar) was an excuse for opening the city up to the sea, thus realising a long-standing aspiration of the citizens, and the Vall d'Hebron, a huge sporting facilities area, provided an opportunity for organising and urbanising a chaotic urban space. ${ }^{76}$ Thus, the host authorities may see mega-sporting events as an opportunity to fund and bring forward long-term projects, which would otherwise remain in the pending file for many years. Portugal, for example, won the right to host the 2004 European Football Championships ahead of favourite Spain even though it had poorer stadiums and transport facilities. Giving the tournament to Portugal was seen as a way of helping both the country's football and overall sporting development. ${ }^{57}$

The 2000 Sydney Games continued the theme of major urban change. The organisers spent $\mathrm{A} \$ 1 \cdot 7$ billion on the construction of sporting facilities, in addition to $\mathrm{A} \$ 1.15$ billion on supportive infrastructure. ${ }^{79}$ The latter included spending A $\$ 137$ million in rehabilitating polluted sites in the area of Homebush Bay, which became the sporting centre during the Games. Similarly, in Athens, the host Olympic city of 2004, besides the creation and renewal of several sporting facilities, a $£ 1.4$ billion new airport opened in 2001 able to handle 16 million passengers and
220000 t of cargo a year. Moreover, the $£ 820$ million expansion of the city's underground was completed in early 2001 with the new lines, carrying a total of 150 million passengers a year, thus creating 3000 full-time jobs. Furthermore, it is estimated that US $\$ 1$ billion will be spent between 2000 and 2004 on projects that are not essentially Games-related but have been triggered by the staging of the event. ${ }^{80}$

The impact of the games on the physical environment includes the building of new sport facilities, accommodation, changes to the look of the city, and transport links as well as industrial space (Table 3).

For Athens 2004, the estimates for industrial space are much higher, with the total figure raising to $1 \cdot 1$ million sq $\mathrm{ft}$, already leased for Olympic-related use. ${ }^{81}$

Mega-sporting events can also provide opportunities to the host sporting authorities to undertake joint projects in order to serve multiple purposes. In Atlanta, for example, the Olympic Stadium has been converted to the home of the city's baseball team. Funding for the $\$ 120$ million stadium came from the 1996 Olympic organising committee, while the additional \$35 million required for the conversion was raised by the Atlanta Braves, Turner Broadcasting and Time Warner. ${ }^{82}$ Similarly, in Manchester, the host city of the 2002 Commonwealth Games, the Sportcity, a 45000 seat stadium, is a joint project of the organisers and the Manchester City Football Club and home of the local football team. ${ }^{83}$

Although the staging of a mega-sporting event can contribute to the urban improvement of the host city or region, attention should be placed on the processes involved for accomplishing major construction projects. As Lenskyj ${ }^{12}$ points out, the set deadline for the construction of venues and the completion of infrastructure supports are often used by local politicians as the excuse for major constructions to bypass the usual stages in urban development applications, including social and environmental assessment, public hearings, and so on. In Athens, for example, the host city of the 2004 Olympics, the decision

\begin{tabular}{|c|c|c|c|c|}
\hline Space user & Use & $\begin{array}{l}\text { Approx. } \\
\text { start }\end{array}$ & Type of space & $\begin{array}{l}\text { Estimates: } \\
\mathrm{m}^{2}\end{array}$ \\
\hline $\begin{array}{l}\text { Vancouver Organising } \\
\text { Committee for the } \\
\text { Olympic Games }\end{array}$ & $\begin{array}{l}\text { Storage and distribution of } \\
\text { supplies: fences, tents, } \\
\text { portable toilets, volunteer } \\
\text { uniforms, trash cans, etc. }\end{array}$ & 2009 & Warehouse & $7000-14000$ \\
\hline Broadcasters & $\begin{array}{l}\text { Storage of supplies, equipment } \\
\text { and for high-end video } \\
\text { assembly work }\end{array}$ & 2008 & Warehouse & $9300-14000$ \\
\hline $\begin{array}{l}\text { Public safety command } \\
\text { security system }\end{array}$ & $\begin{array}{l}\text { Conducting background checks, } \\
\text { processing credentials, } \\
\text { staging area, supplies storage }\end{array}$ & 2009 & Warehouse & $2800-5600$ \\
\hline Sponsors & $\begin{array}{l}\text { Storage, assembly, staging area, } \\
\text { preparation }\end{array}$ & 2009 & Warehouse & $4600-14000$ \\
\hline $\begin{array}{l}\text { Other (including sports } \\
\text { governing associations, } \\
\text { national Olympic } \\
\text { committees) }\end{array}$ & Storage, staging area & $2008-2010$ & Warehouse & $2300-7000$ \\
\hline Total & & & & $26000-54600$ \\
\hline
\end{tabular}


about the construction of the rowing centre for the Games at the Marathonas Lake was criticised for lacking adequate environmental analysis. It has been claimed that the project will undermine the natural resources of the waterland and cause collateral damage in the area. ${ }^{84}$

The staging of a mega-sporting event may pose additional environmental problems, especially when temporary structures are built for the needs of the event. At the Atlanta Games, for instance, four sports were hosted in temporary facilities which had to be demolished after the Games because of their limited usefulness to the local community. ${ }^{12}$ In this case, the practices of disposing of such material, which cannot be recycled, fail to qualify as ecologically sustainable development. Finally, when infrastructure projects speed up, other public works can be delayed or displaced. Moreover, when a large proportion of state funds are channelled into one metropolitan area, this often results in fewer infrastructure projects in suburban areas and in other regions. ${ }^{71}$ The choice for such projects is usually a political one, since the cost of the often extensive event-related infrastructure is primarily covered by local governments. ${ }^{8}$ This, in turn, stresses the role of governments and the subsequent politics involved in hosting a mega-sporting event, which is presented below.

\subsection{Political impacts}

The staging of a mega-sporting event of the significance of the Olympic Games or the Football World Cup usually has as its central constituent local, regional or even central governments. The main reason for that is that the administration of such events produces difficulties in covering the cost for the supportive infrastructure of the event or even for operating costs from tickets sales, sponsorship, television rights and so on, and therefore, governments' economic contribution is often required. ${ }^{8}$ For instance, the cost of the sporting and supportive infrastructure of the 2000 Sydney Olympics was mostly covered by the government of New South Wales which, in addition, provided several economic bailouts to the organisers to cover their operating costs. ${ }^{79}$

Inevitably, therefore, the decision to bid for hosting a megasporting event is backed by governments, which frequently initiate such decisions, especially when the event provides the potential to pay them back in the form of economic, physical or other benefits. Public governance is mostly involved in such decisions at a local or regional level, since, with the exception of football events, mega-sporting events are awarded to cities rather than countries. Moreover, as Harvey ${ }^{37}$ points out, local governments have become comparatively autonomous from central governments, and as a result, they have adopted less bureaucratic and more competitive practices. Under this transformation, the competition to host and manage megasporting events has been an integral part of urban politics. Cochrane and Peck ${ }^{40}$ illustrate some of the key features of this new urban politics through the example of Manchester's Olympic bids of the 1980s and 1990s, in which local government-based decision making and bureaucratic politics were essentially replaced by a dynamic business leadership.

Hall $^{85}$ suggests that the decisions affecting the hosting of a megaevent grow out of a political process which not only involves the interests of political authorities, but also those of private, profit-oriented organisations. The New South Wales government in Australia, for instance, which was heavily involved in the organisation of the Sydney 2000 Olympics, has adopted more entrepreneurial-driven forms of governance, since a broad range of non-government, often private, organisations were incorporated into the NSW Government's decision making and policy formulation process. ${ }^{34}$ Therefore, under the new urban politics imperatives, a decision to bid for mega-events, such as the Olympics, is not solely made by local or regional governments but often involves business corporations. ${ }^{29}$ In that sense, mega-sporting events are often credited with mobilising corporate elites and local politicians in profitable alliances that not only can boost local construction and retail and tourist industries but can also generate substantial infrastructure funding from higher levels of government. The practices of such alliances, which are termed by Lenskyj ${ }^{12}$ as 'Politics of Place', usually involve campaigns to persuade the citizens of the host city that the event will transform their hometown into a "worldclass' city, thus justifying the use of tax money. However, Eitzen, ${ }^{56}$ through his analysis of Toronto's bid for the 2008 Olympics, has claimed that taxpayers disproportionately bear the burden when they give consent for the use of tax money for the staging of mega-sporting events. For example, he has provided sufficient evidence that the policy of the bid committee regarding the sporting infrastructure was primarily focused on the needs of professional sport.

Throughout the years of the Olympic preparations, an organising committee for the Games creates links with various external organisations, which often constrain its operations, as the case of Sydney illustrates. In particular, the Sydney organising committee was in need of financial resources from the International Olympic Committee, the New South Wales Government and the Olympic sponsors, human resources from Australian Trade Unions and the general public in the form of staff and volunteers, expert knowledge from the International Federations as well as physical resources provided by the regional government in the form of Olympic-related infrastructure (Fig. 1).

Moreover, corporate legitimacy, although intangible in nature, was an essential externally held resource for the organising committee. Corporate legitimacy is used here to refer to the legal

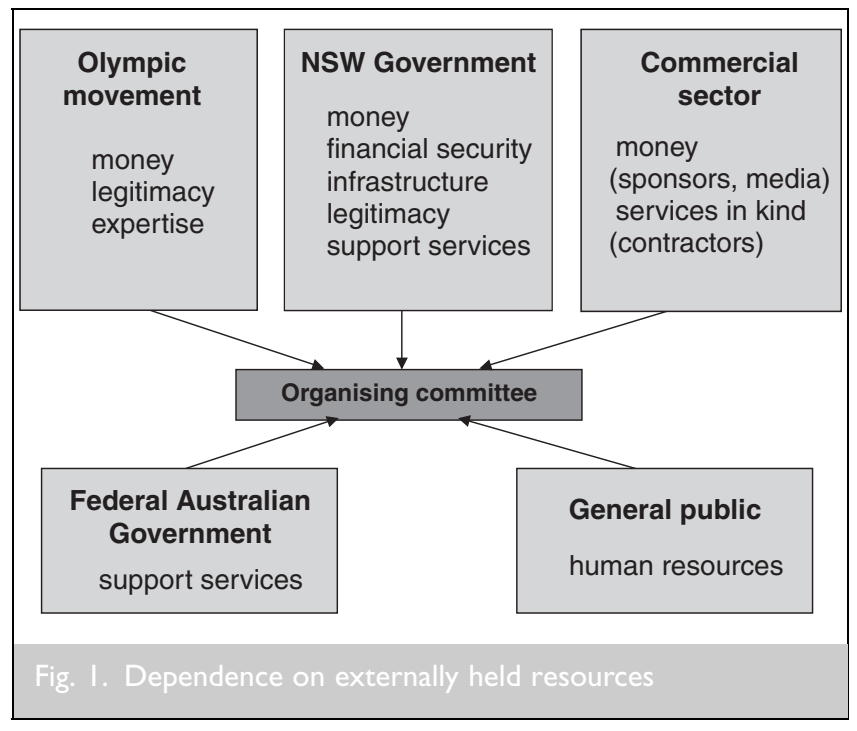


arrangements made as much by the International Olympic Committee as by the regional government in order to provide the organising committee with the appropriate legal status and authority to operate. Such arrangements do not only include the host city contract, which specified the broader legal framework, but also a series of legal agreements. Overall, therefore, resources held by external actors were important to the organising committee throughout its life cycle.

The organising committees of mega-sporting events frequently include elected representatives who serve as their members or even presidents, such as in the case of a New South Wales Parliament Member, who was also the President of the Sydney 2000 organising committee. Such politicians often experience conflicting pressures to represent taxpayers' interests on the one hand, and profit-oriented interests on the other. The dual role of the Member, for example, was promoted by the NSW government as a major factor in keeping the project on target and on budget; however, it was claimed that the Olympics were compromised when the Member, as Cabinet Minister, was not able to criticise the Government's handling of issues such as the contamination of Sydney's water supply due to Olympic works, and its serious implications for Olympic tourism. ${ }^{12}$ In Sydney's case, the 'Olympics as catalyst' rhetoric attracted a lot of criticism, since politicians and businessmen who had promised dramatic improvements in the lead up to the Olympic bid failed to take adequate action when urban social problems were equally urgent. $^{12}$

Finally, an additional political application of staging a megasporting event is what Ritchie ${ }^{73}$ refers to as a micro-political factor. This applies to the desire of individuals to utilise the visibility offered by the involvement with an event with a view to enhancing their careers in both political and non-political arenas. Indeed, politicians who are involved in the organisation of prestigious sporting events, such as the Olympics, have the opportunity to improve their political image by associating themselves with the event, as well as to develop their public relations through contacts with sporting authorities and commercial organisations involved in the event. The case of the President of the Sydney 2000 Organising Committee, for instance, who retired from politics after the Games and is now working for the International Olympic Committee, might be seen as such an example.

Our discussion about the impacts of mega-sporting events suggests that such events can produce both positive and negative impacts for the host cities, regions or countries. It has been demonstrated that nearly all the positive applications of such events have also a negative side, which is often expressed in academic debates. However, what can be seen as indisputable is that mega-sporting events can benefit the managerial practices and capacities of the organising authorities. The sporting authorities involved in the organisation of a mega-sporting event can benefit by obtaining experience essential for organising future sport events. It has been reported, for example, that for the Barcelona sports world the organisation of the 1992 Olympic Games was a tremendous opportunity for improving its methods of management and its organisational capacity, for linking up better with the international sports network, and therefore for being better prepared to serve the city's daily sports requirements. Sport clubs, sporting federations, and sports management companies have also benefited from the accumulated know-how, having improved their workforces with the addition of workers involved with the organising committee of the Games. ${ }^{76}$ The organisers of mega-sporting events the size of the Olympics cooperate with international federations, corporate sponsors, broadcasting corporations, governmental authorities, and the like. Individuals, therefore, can acquire sport-specific managerial experience, which can then be returned as a benefit to the sport administration of the host country, and can also provide these countries with a considerable advantage when they wish to stage future sporting events. Moreover, the organisation of complex events, such as the Olympic Games, which often requires business-like management, can improve the practices of the public administration. In Greece, for example, the Olympic preparations for the 2004 Games, which required the creation of many temporary companies, triggered the restructuring of the legal framework concerning the creation of public corporations and limited companies. In particular, the time span for establishing such organisations was dropped to one week from the two months that previously existed. ${ }^{86}$

While under the Olympic spotlight, local and national governments are often forced to take particular political steps to showcase their strengths and conform to international political pressures. ${ }^{87}$ For example, it is alleged ${ }^{88}$ that the Olympic preparations in Athens added extra momentum to the attempts to catch the 17th November terrorist group members. Under the international climate of fear of terrorist threats and in light of the heightened vulnerability of Athens as an Olympic capital in the Balkan region, civil liberties are also expected to suffer by draconian security measures.

\section{CONCLUSIONS}

This paper reviews current literature on mega sporting events and the Olympic Games as case examples to illustrate the forms of impact on the host city and country. The defining features of such mega-events have been identified in the literature as the degree of impact, the scale of the duration, the organisational complexity and involvement of various agents.

Due to the increasing size, the staging of the Olympics currently involves considerable investment in both sporting facilities, and supporting infrastructure and services, such as in accommodation, transportation and telecommunications. Such a costly, complex and high-profile activity as hosting the Olympic Games involves various interests ranging from the commercial, with their concern to maximise profit, to the governmental, with their concern for political, social and economic benefits. Specifically for the host cities, the benefits to be derived from staging the Games can be enormous and various. For example, they can promote economic activity as a result of the jobs created in hospitality-related sectors. The construction of sports facilities can also play a role in programmes of urban renewal by, for example, introducing new sporting and recreational facilities into previously under-provided areas. On a broader scale, preparations for the event can also provide a means of justifying new investment in transport infrastructure and in projects to enhance the city's landscape and physical appearance. In the case of the Greek State an estimated US $\$ 1.6$ billion is being spent on Games-related projects. ${ }^{9,10}$ 
Drawing examples from recent mega-events, the discussion on impacts has highlighted positive as well as negative ones and provided examples of how structures as well as acting human agents affect outcomes. Increased city awareness, economic development, job creation and urban regeneration have been witnessed along with high inflation, expensive housing, threats to civil liberties of certain groups, terrorist acts and even city defamation after revelations of bribery scandals.

It is nevertheless argued that the International Olympic Committee, together with local Olympic organisers and public relations experts, has largely succeeded in maintaining the illusion that, while negative impacts as well as tensions may manifest themselves in malpractices or boycotts, the sport world is unequivocally supportive of the Olympic venture. ${ }^{89}$ Therefore, despite the widespread criticisms surrounding the institution of the Olympic Games, which mainly challenge the connection between the ideas of Olympism and the contemporary nature of the event, the Games continuously grow in magnitude and significance. In effect, the contemporary Olympics sustain the status of a mega-event, and economic benefits are the prime motive for all the interests involved in the hosting of the Games, be it the local Government, which seeks urban development of the region through infrastructure made for the staging of the event, or the corporation that becomes a sponsor of the event to attract publicity. While bidders battle for the kudos of winning the hosting of a mega-event, the desired economic, fiscal, social, cultural and political outcomes are expected to justify their actions. Further research in the area is necessary to judge the benefits of such undertakings in light of costs and potential negative impacts.

\section{REFERENCES}

1. Roche M. Mega-Events and Modernity: Olympics and Expos in the Growth of Global Culture. Routledge, London, 2000.

2. LuCAS J. A. The Future of the Olympic Games. Human Kinetics, Champaign, Illinois, 1992.

3. Mеснісоғ B. Olympism: the humanitarian philosophy of the new millennium. Proceedings of the 8th IOA International Postgraduate Seminar, Olympia, Greece, May-June 2000 (Unpublished paper).

4. International Olympic Committee. IOC Olympic Charter. IOC, Lausanne, 1999.

5. International Olympic Committee. Marketing Revenue: Facts and Figures of the International Olympic Committee. IOC, Lausanne, 2004. Available at: http://www.olympic. org/uk/organisation/facts/revenue/index_uk.asp.

6. Jennings A. and SAmBrooK C. The Great Olympic Swindle: When the World Wanted its Games Back. Simon and Schuster, London, 2000.

7. NAsh R. and Johnstone S. The case of Euro96: where did the party go? Proceedings of 'Sport in the City' Conference, Sheffield, 2-4 July 1998.

8. Preuss H. Economics of the Olympic Games: Hosting the Games 1972-2000. Walla Walla Press, Sydney, 2000.

9. Athens 2004 Television Rights and the Athens Games. June Press Release, Athens 2001, 2004.

10. Athens 2004 Corporate Sponsors. Annual Report of the Athens 2004 Olympic Games Organising Committee. ATHOC, Athens, 2003. Available at: http://www.athens2004.com/ athens2004 $/$ page $/$ legacy?lang $=$ enctcid $=6 \mathrm{~d} 08470429$ 149f00VgnVCMServer28130b0aRCRD.

11. International Olympic Committee. IOC Annual Report. IOC, Lausanne, 2001.

12. LeNSKY J. H. Inside the Olympic Industry: Power, Politics and Activism. State of New York University Press, Albany, 2000.

13. INGERSON L. A comparison of the economic contribution of hallmark sporting and performing events. In Sport and the City: the Role of Sport in Economic and Social Generation (Gratton C. and Henry I. (eds)). Routledge, London, 2001.

14. HALl C. M. Hallmark Tourist Events. Belhaven Press, London, 1992.

15. Getz D. Event management and event tourism. Annals of Tourism Research, 1998, 25, No. 1, 248-249.

16. Hill C. Olympic Politics. Manchester University Press, Manchester, 1992.

17. Whitson D. and Macintosh D. The global circus: international sport, tourism, and the marketing of cities. Journal of Sport and Social Issues, 1996, 23, No. 2, $278-295$.

18. De Moragas M. and Botela M. The Keys to Success. Centre d'Estudis Olimpics i de l'Esport, Universitat Autonoma de Barcelona, Barcelona, 1995.

19. Toohey K. and Veal A. J. The Olympic Games: A Social Science Perspective. CABI Publishing, Wallingford, 2000.

20. MoRphet J. The real thing. Town and Country Planning, 1996, 65, No. 11, 312-314.

21. De Moragas M. Television, sport and the Olympic Movement. Olympic Message, 1996, 26, No. 1, 77-82.

22. Dayan D. and Katz E. Media Events. Harvard University Press, Cambridge, Mass., 1992.

23. Jackson P. and McPhail T. The Olympic Movement and the Mass Media. Hurtford Enterprises, Calgary, 1989.

24. Roche M. Mega-events and urban policy. Annals of Tourism Research, 1994, 21, No. 1, 1-19.

25. DAVIES L. Sport in the city: measuring the economic impact in Sheffield. In Sport and the City: the Role of Sport in Economic and Social Generation (GRATTON C. and HenRy I. (eds)). Routledge, London, 2001.

26. Roche M. Mega-events, culture and modernity: expos and the origin of public culture. International Journal of Cultural Policy, 1999, 5, No. 1, 1-31.

27. Sola F. E. The impact of mega-events. Annals of Tourism Research, 1998, 25, No. 1, 241-245.

28. EMERY R. P. Bidding to host a major sport event: strategic investment or complete lottery? In Sport and the City: the Role of Sport in Economic and Social Generation (Gratton C. and Henry I. (eds). Routledge, London, 2001.

29. Essex S. and ChalkLey B. Olympic Games-catalyst of urban change. Leisure Studies, 1998, 17, No. 3, 187-206.

30. Shibli S. and Gratton C. The economic impact of two major sporting events in two of the U.K's National cities of sport. In Sport and the City: the Role of Sport in Economic and Social Generation (Gratton C. and Henry I. (eds)). Routledge, London, 2001.

31. Kitchen T. Cities and the 'world events' process. Town and Country Planning, 1996, 65, No. 11, 314-317.

32. STEVEnS T. Olympic gains. Leisure Management, 1996, 16, No. 7, 34-37.

33. Gratton C. and Henry I. Sport and the City: the Role of Sport in Economic and Social Generation. Routledge, London, 2001. 
34. Dunn M. K. and McGuiRK M. P. Hallmark events. In Staging the Olympics: The Event and its Impacts (CASHMAN R. and Hughes A. (eds)). Centre for Olympic Studies, UNSW, Sydney, 1999.

35. Kearns G. and Philo C. Selling Places: The City as Cultural Capital, Past and Present. Pergamon Press, New York, 1993.

36. Graham S. and Marvin S. More than ducts and wires: post Fordism, cities and utility networks. In Managing Cities: The New Urban Context (Healey P., Cameron S., Davoudi S., Graham S. and Madanipour A. (eds)). Wiley, London, 1995, pp. 169-189.

37. HaRvey D. The Urban Experience. Blackwell, Oxford, 1989.

38. Hughes H. Olympic tourism and urban regeneration. Festival Management and Event Tourism, 1993, 1, No. 1, 157-162.

39. Mules T. A special event as part of an urban renewal strategy. Festival Management and Event Tourism, 1993, 1, No. 1, 65-67.

40. Cochrane A. and Peck J. Manchester plays games: exploring the local politics of globalisation. Urban Studies, 1996. 33, No. 8, 1319-1336.

41. International Olympic Committee. IOC Annual Report, IOC, Lausanne, 2003.

42. Horne J. and MAnZenreiter W. Japan, Korea and the 2002 World Cup. Routledge, London, 2002.

43. LAWSON T. After it s all over. Geographical Magazine, 1996, 68, No. 7, 20-24.

44. PARK J. Factors Contributing to Mega-event City Selection. Unpublished $\mathrm{PhD}$ thesis, University of Illinois at UrbanaChampaign, 2003.

45. Guarinello E. The Promise of the Games: Imagination and the Washington, D.C. 2012 Olympic Bid. Unpublished thesis, Department of Growth and Structure of Cities, Bryn Mawr College, PA, USA, 2001.

46. CROMPTON J. Economic analysis of sport facilities and events: eleven sources of misapplication. Journal of Sport Management, 1995, 9, No. 1, 14-35.

47. PReUSS H. Problemizing the Arguments of the Opponents of Olympic Games. Unpublished paper, Johannes GutenbergUniversity Mainz, Germany, 1998.

48. State of Utah. 2002 Olympic Winter Games: Economic, Demographic and Fiscal Impacts. Governor's Office of Planning and Budget, Utah, 2000.

49. Ference Weicker \& Co. Impact of 2010 Olympic Winter Games and Paralympic Games on Vancouver's Inner City Neighbourhoods. Ference Weicker \& Co., Vancouver, 2002.

50. Avison Young. Avison Young Olympic Impact: Vancouver 2010 and the Industrial Real Estate Market. Avison Young, Vancouver, 2003.

51. Miguelez F. and Carrasquer P. The repercussion of the Olympic Games on labour. In The Keys to Success (De Moragas M. and Botela M. (eds)). Centre d'Estudis Olimpics i de l'Esport, Universitat Autonoma de Barcelona, Barcelona, 1995.

52. Pyo S., Cook R. and Howell R. Summer Olympic tourism market: learning from the past. Tourism Management, 1988, 9, No. 2, 137-144.

53. Kang S. and Perdue R. Long-term impact of a mega-event on international tourism to the host country: a conceptual model and the case of the 1988 Seoul Olympics. The Journal of International Consumer Marketing, 1994, 6, No. 3/4, 205-225.
54. KeMP J. Beyond the Games: Assessing the Impact of the 2002 Olympic Winter Games and the Future of Utah tourism. Utah Division of Travel Development, Utah, 2002.

55. Tudge R. The impacts of the Olympics on existing travel in Sydney. Traffic Engineering and Control, 2003, 44, No. 1, $28-30$.

56. EITZEN D. S. Classism in sport: the powerless bear the burden. Journal of Sport and Social Issues, 1996, 20, No. 1, 95-105.

57. Stevens T. and BeVAn T. Olympic legacy. Sport Management, 1999, 19, No. 9, 16-19.

58. BRUNET F. An economic analysis of the Barcelona '92 Olympic Games: resources, financing and impact. In The Keys to Success (De Moragas M. and Botella M. (eds)). Centre d'Estudis Olimpics de l'Esport, Universitat Autonoma de Barcelona, Barcelona, 1995.

59. Schimmel K. S. Growth politics, urban development, and sports stadium construction in the United States: A case study. In The Stadium and the City (BALE J. and Moen 0. (eds)). Keele University Press, Keele, 1995.

60. Hiller H. H. Mega-events, urban boosterism, and growth strategies: an analysis of the objectives and legitimations of the Cape Town 2004 Olympic bid. International Journal of Urban and Regional Research, 2000, 24, No. 2, 439-458.

61. Dobson N., Holliday S. and GRATTON C. Football came home. Sport Management, 1997, 17, No. 5, 16-19.

62. Chaudhary V. Golden goals. Guardian, March, 1999, 23.

63. De Knop P. and Standeven J. Ready for action. Sport Management, 1999, 19, No. 5, 18-20.

64. Ritchie J. R. and Sмiтh H. B. The impact of a mega-event on host awareness: a longitudinal study. Journal of Travel Research, 1991, 30, No. 1, 3-10.

65. Mossberg L. The event market. Annals of Tourism Research, 1997, 24, No. 3, $748-751$.

66. Hellenic Tourism BoARD. Tourists' arrivals in Greece. Hellenic Tourism Board, Athens, 2004.

67. Hall C. M. and Hodges J. The politics of place and identity in the Sydney 2000 Olympics: sharing the spirit of corporatism. In Sport, Culture and Identity (Roche M. (ed.)). Meyer and Meyer Verlag, Aachen, 1998.

68. BeAty A. The homeless Olympics? In Homelessness: the Unfinished Agenda (JAmes C., South J., BeEston B. and Long D. (eds)). University of Sydney, Sydney, 1999.

69. Horin A. Budget hotels baulk at rooms for homeless during Games. Sydney Morning Herald, 15 September 1998, 12.

70. Horin A. State of despair haunts a score of western suburbs. Sydney Morning Herald, 8 June 1999, 13.

71. RuthHeISer D. Imagineering Atlanta. Verso, New York, 2000.

72. Preuss H. Economic aspects of the Olympic Games and possible consequences of a corruptive practice of allocation. In Blickpunkt Olympia: Entdeckungen, Erkentnisse, Impulse (Muller N. and Messing M. (eds)). Olympishe Studien Bd, 5, 322-336, Kassel: Agon Sportverlag.

73. Ritchie J. R. Assessing the impact of hallmark events: conceptual and research issues. Journal of Travel Research, 1984, 23, No. 2, 2-11.

74. LoNDon 2012. Short listing of candidate cities. February Press Release, London 2012, London, 2004.

75. HoOper I. The value of sport in urban regeneration. In Sport and the City: the Role of Sport in Economic and Social Generation (GRATTON C. and HenRY I. (eds)). Routledge, London, 2001. 
76. TRuno E. Barcelona: city of sport. In The Keys to Success (De Moragas M. and Botella M. (eds)). Centre d'Estudis Olimpics i de l'Esport, Universitat Autonoma de Barcelona, Barcelona, 1995.

77. De Guevara L. M., Coller X. and Romani D. The image of Barcelona in the international press. In The Keys to Success (De Moragas M. and Botela M. (eds)). University of Barcelona, Barcelona, 1995.

78. TheodoraKi E. The making of the UK Sports Institute. Managing Leisure: an International Journal, 1999, 4, No. 4, $187-200$.

79. NSW Government. Budget statement of the New South Wales Government 2000-2001. In Sydney Olympic and Paralympic Games. NSW, Sydney, 2001, Ch. 6.

80. Tzelis K. Athens 2004: timetable for the works. Imerisia, 29 June 2001, 6 (translated from Greek).

81. Danos And Associates. The Impact of the Athens 2004 Olympics on the Commercial Real Estate Market. Danos and Associates, Athens, 2003.
82. Cramer J. Brave start. Leisure Management, 1997, 17, No. 5, $20-23$.

83. MANChester 2002. The city will rise to the challenge. Electronic publication (commonwealthgames2002.org.uk), December 15, 1999.

84. Mberi N. Civil war at Marathonas. Eleftherotypia, 30 April 2001, 17 (translated from Greek).

85. Hall C. M. The effects of hallmark events on cities. Journal of Tourism Research, 1987, 26, No. 2, 44-45.

86. Christodoulakis A. G. Procedures-express for the creation of new companies. To Vima, 2001, 24 August, B4.

87. Burbank M., Andranovich G. and Heying C. Olympic Dreams: the Impact of Mega-events on Local Politics. Lynne Rienner Publishers, Boulder, 2001.

88. Ntaliani D. Arrest of 17th November members. Ta Nea, 15 March 2003 (translated from Greek).

89. Fuller S. and Cuinch R. The Economic and Fiscal Impact of Hosting the 2012 Olympic Games on the WashingtonBaltimore Metropolitan Area. Merrick Business School, University of Maryland, Baltimore, 2002.

Please email, fax or post your discussion contributions to the secretary by I March 2005: email: kathleen.hollow@ice.org.uk; fax: +44 (0)20 7799 1325; or post to Kathleen Hollow, Journals Department, Institution of Civil Engineers, I-7 Great George Street, London SWIP 3AA. 